\title{
ПСИХОЛОГИЯ
}

DOI: $10.17805 / g g z .2018 .5 .6$

\section{Личностные факторы эмоционального выгорания педагогов коррекционной школы*}

\author{
Т. П. Емельянова
}

Московский гуманитарный университет; Институт психологии РАН, Е. И. Шуралева

Московский гуманитарный университет

В статье представлены результаты анализа личностных особенностей педагогов коррекиионной школы с разным уровнем эмоционального выгорания. Респондентами выступили 72 педагога коррекиионной школы, расположенной в Московской области.

С помощью данных личностного опросника «Профессиональное выгорание» респонденты были разделены на две группы с разным уровнем эмочионального выгорания. Применение опросника «Ценностные ориентации», теста «САМОАЛ» и методики «Незаконченные предложения» позволило обнаружить, что для педагогов с уровнем эмоционального выгорания выше среднего характерна тенденция к меньшей креативности, ригидность мышления и поведения, меньшая контактность и при этом большая зависимость от окружающих, затруднения в поддержании равных, партнерских взаимоотношений. Эти педагоги изолируют себя от окружающих и их поддержки, а также не используют ресурс смены видов деятельности. Для них достоверно в большей степени значимо материальное благосостояние, и менее важно признание со стороны других людей, помощь и милосердие как иенности, чем для педагогов с низким уровнем выгорания.

Педагоги с уровнем эмоционального выгорания выше среднего демонстрируют недостаточную ясность общих стремлений, жизненных и профессиональных ориентиров, что выступает существенным дезорганизующим фактором, способным усугублять профессиональное выгорание педагога. Педагоги с уровнем эмоционального выгорания ниже среднего отличаются тем, что испытывают интерес к выполняемой деятельности, общению с учашимися и педагогами. В случае усталости они быстро восстанавливаются, их самооченка профессиональной успешности выше, они удовлетворены своими результатами в настоящем и строят планы на будущее.

\footnotetext{
* Исследование выполнено в рамках госзадания № 0159-2018-0003.

The study was carried out by State order No. 0159-2018-0003.
} 
Ключевые слова: эмочуиональное выгорание; педагоги коррекционных икол; личностные особенности; иченностные ориентации; самоактуализацุия

\title{
Personal Factors of Emotional Burnout among Correctional School Teachers
}

\author{
T. P. Emelyanova \\ Moscow University for the Humanities; Institute of Psychology, \\ Russian Academy of Sciences, \\ E. I. Shuraleva \\ Moscow University for the Humanities
}

The article presents the results of an analysis of the personal features of correctional school teachers with different levels of emotional burnout. The respondents were 72 teachers working in a correctional school, which is located in Moscow Oblast.

They have been divided into two groups with different levels of emotional burnout with the help of the personal questionnaire "Professional burnout". The use of the questionnaire "Value orientations", the test for personal self-actualization and the "Unfinished sentences" methodology made it possible to find out that teachers, whose emotional burnout is above average, have a tendency to reduced creativity, rigidity of thinking and behavior, worse in-touch capabilities and at the same time they have great dependence on other people, difficulties in maintaining equal, partnership relations. These teachers isolate themselves from other people and their support, and do not use the opportunities of changing activities. Material well-being is significantly more important for them, and recognition from other people, help and mercy as values are less important than for teachers with low burnout scores.

Teachers, who have above average level of emotional burnout, demonstrate insufficient clarity of common aspirations, life and professional orientations. This is a significant disorganizing factor that can increase the professional burnout of the teacher. Teachers with below average burnout level differ because they are interested in activities and communication with students and teachers. If they get tired, they quickly regain their strength. Their self-assessment of professional success is high; they are satisfied with their results in the present and make plans for the future.

Keywords: emotional burnout; correctional school teachers; personal characteristics; value orientations; self-actualization 


\section{ВВЕДЕНИЕ}

Феномен эмоционального выгорания обусловлен воздействием с одной стороны, внешних факторов таких, как специфика деятельности, условия труда, предмет труда, а, с другой, факторов внутренних, прежде всего, личностных: мотивацией деятельности субъекта труда, его психоэмоциональными характеристиками, способностями, ценностными ориентациями, интересами и т. п. При этом ряд авторов считает, что внутренний фактор является ведущим. Так С. В. Умняшкина показывает, что синдром эмоционального выгорания значимо связан с особенностями самоактуализации личности (Умняшкина, 2001). Н. В. Гришина трактует эмоциональное выгорание как разновидность профессионального стресса. Автор доказывает, что центральной чертой состояния выгорания является потеря смысла собственной деятельности. В наиболее тяжелых случаях это состояние провоцирует экзистенциальный невроз (Гришина, 2008). Р. М. Айсина выявила существование положительных связей уровня эмоционального выгорания с общим показателем дезинтеграции в ценностной сфере, а также со степенью выраженности «внутренних конфликтов» и «внутренних вакуумов» (Айсина, 2007).

Согласно произведенному В. Е. Орлом анализу теорий эмоционального выгорания (Орел, 2001), в современной психологии существуют несколько подходов к феномену эмоционального выгорания: однофакторная модель А. Пайнса и Э. Аронсона (выгорание как состояние физического, эмоционального и когнитивного истощения), двухфакторная модель Д. Дирендонка, В. Шауфели, Х. Сиксмы (выгорание как феномен, включающий эмоциональное истощение и деперсонализацию) и трехфакторная модель К. Маслач и С. Джексон (выгорание включает эмоциональное истощение, деперсонализацию и редукцию личных достижений). Помимо структурных теорий существуют и динамические подходы к эмоциональному выгоранию как к процессу, существо которого состоит в нарастании эмоционального истощения и в образовании негативных установок к предмету труда.

Среди отечественных разработок одним из наиболее продуктивных нам представляется подход Н. Е. Водопьяновой (Водопьянова, 2000, 2009), которая не только создала развернутую концептуальную модель феномена выгорания, но и адаптировала методику измерения основных показателей синдрома профессионального выгорания К. Маслач и С. Джексон (Maslach, Jackson, 1986).

Педагогическая деятельность как вид профессиональной деятельности ввиду ее специфики отличается большими психоэмоциональными нагрузками. Как показывает Е. А. Василевская, школьные педагоги, характеризуются крайне низкими показателями физического и психологического здоровья, причем эти показатели снижаются с увеличением срока работы в школе (Ba- 
силевская, 2011). По данным В. В. Бойко, из 7300 опрошенных им педагогов общеобразовательных школ у 70 \% отмечались неврозоподобные состояния (Бойко, 1999).

Еще более высоким является риск эмоционального выгорания у педагогов коррекционной школы. Дети с особыми потребностями в образовании - это дети, нуждающиеся в получении особой психолого-педагогической помощи и организации специальных условий при их воспитании и обучении. К данной категории относятся дети с нарушениями зрения, слуха, речи и умственного развития. Высокие показатели эмоционального выгорания у педагогов коррекционных учреждений были обнаружены Т. В. Рединой (Редина, 2010). По результатам, полученным В. Н. Феофановым, умственная отсталость учащихся провоцирует у педагогов, главным образом, развитие симптома деперсонализации. В несколько меньшей степени подвергаются такому риску учителя и воспитатели, работающие с детьми, у которых нарушены речь, слух, зрение, опорно-двигательный аппарат и т. д. (Феофанов, 2008).

Особый интерес представляет выявленная в ряде исследований специфика выраженности различных компонентов (симптомов) эмоционального выгорания у педагогов, работающих с такими детьми. Например, В. Н. Феофанов указывает, что «высокий уровень развития выгорания встречается у значительной, части педагогов специальных (коррекционных) образовательных учреждений и способен привести их к профессиональной деформации» (Феофанов, 2009: 6). Наиболее выражен симптом, для которого характерны сниженный эмоциональный фон, индифферентность, эмоциональное перенасыщение, чувство усталости и опустошенности. Вторую позицию в синдроме психического выгорания педагогов коррекционной школы занимает симптом «редукции личных достижений». Несколько реже встречается симптом «деперсонализации» (Феофанов, 2008).

Эмоциональное выгорание у педагогов коррекционной школы сопряжено с развитием эмоциональных нарушений (вплоть до неврозов), обесцениванием значимости и результатов собственной деятельности, которая при этом требует существенных усилий, а также нарушением межличностных отношений с окружающими, что самым негативным образом сказывается на качестве жизни педагога.

Необходимо заметить, что деструктивные изменения у педагога, подверженного эмоциональному выгоранию, наблюдаются и в области взаимоотношений с учащимися. По данным В. Н. Феофанова, «педагог с высоким уровнем психического выгорания оказывает негативное влияние на формирование эмоционального отношения к нему со стороны учащихся с особыми образовательными потребностями и привлекательности для детей школьной ситуации в целом» (там же). Кроме того, наблюдаются другие факторы эмо- 
ционального выгорания педагогов коррекционной школы. В частности, к ним относится низкий уровень специальной дефектологической подготовки. Недостаточный профессиональный уровень в области дефектологии ведет к появлению признаков эмоционального истощения, и наоборот, высокий уровень подготовки способствует продуктивной работе специального педагога.

Между тем, исследуя риски эмоционального выгорания у педагогов коррекционных школ, Т. В. Редина отмечает, что личностные факторы занимают ведущее место в иерархии факторов, которые связаны с эмоциональным выгоранием педагогов, работающих с детьми с особыми образовательными потребностями (Редина, 2010). Автор показывает, что личностные особенности педагогов играют одну из главных ролей в возникновении эмоционального выгорания и в способности их справляться с последствиями стрессовых ситуаций. В частности, акцентуации характера педагогов коррекционной школы усугубляются под влиянием профессиональных стрессов и ведут к социальной дезадаптации, повышая вероятность развития эмоционального выгорания (там же: 227). При этом педагоги с высоким уровнем эмпатии, работающие в коррекционных школах, в большей степени защищены от эмоционального выгорания. Показано также, что процессы самоактуализации действуют как механизмы резистентности и совладания с выгоранием (см., например: Умняшкина, 2001). При этом психологическая гибкость, включающая эгоустойчивость, исполнительный контроль, модуляцию ответа, саморегулирование, рассматривается как один из динамических процессов, имеющих временную протяженность. Имеет значение то, как педагог адаптируется к изменяющимся ситуационным требованиям, перенастраивает свои интеллектуальные ресурсы. И, наоборот, психологическая ригидность рассматривается как фактор эмоционального выгорания.

Проблема эмоционального выгорания связывается исследователями и с духовно-нравственной сферой личности (Психологическое здоровье личности ..., 2014). Термины «духовное здоровье», «душевное здоровье», «духовно-нравственное здоровье» в этом контексте являются аналогами понятия психологического здоровья. Удачную попытку применения понятия психологического здоровья педагога в контексте исследования проблемы эмоционального выгорания предприняла Е. В. Федосенко. В ходе исследования автором выявлена факторная структура психологического здоровья педагога, которая включает духовный фактор или «направленность на других, служение другому» и «самореализация» («Я для мира»); индивидуально-личностный фактор или «направленность на себя» («Я для себя») и социальный фактор («Мир для меня») (Федосенко и др., 2012).

Хотя в отечественной психологии проведен целый ряд исследований проблемы эмоционального выгорания педагогов коррекционных школ, необ- 
ходимо заметить, что некоторые стороны проблемы требуют дальнейшего изучения. Особенно следует обратить внимание на связь ключевых для профессии педагога личностных особенностей (самоактуализации и ценностных ориентаций) с уровнем его эмоционального выгорания. Для анализа данной проблемы было проведено наше эмпирическое исследование.

\section{ПРОГРАММА ИССЛЕДОВАНИЯ}

Цель исследования - выявление личностных особенностей педагогов коррекционной школы с разным уровняем эмоционального выгорания.

Методики. Для диагностики уровня эмоционального выгорания был применен опросник «Профессиональное (эмоциональное) выгорание», разработанный на основе трехфакторной модели К. Маслач и С. Джексон и адаптированный Н. Е. Водопьяновой и Е. С. Старченковой. С целью изучения структуры ценностных ориентаций педагогов была использована методика С. С. Бубновой «Диагностика реальной структуры ценностных ориентаций личности». Для исследования уровня самоактуализации был использован тест по выявлению преобладающих сфер самоактуализации личности «САМОАЛ». С целью выявления представлений о профессиональных целях и способах преодоления трудностей у педагогов коррекционной школы применялся авторский вариант методики «Незаконченные предложения». Педагогам предлагалось завершить следующие предложения:

1. Я вижу свою профессиональную цель в том, чтобы...

2. Психологические сложности в работе мне помогает преодолевать...

3. Я стремлюсь...

4. Мой успех связан...

5. Мой профессиональный интерес направлен на...

Для проверки достоверности различий между показателями групп были использованы коэффициенты Стьюдента. Расчеты произведены в программе Statistica 10.0 .

Описание выборки. В исследовании принимали участие 72 работника коррекционной школы (учителя и воспитатели). Средний возраст испытуемых 43 года, средний стаж работы в данной организации 16,5 лет. В браке состоят 56 человек (77,8 \%), не состоят в браке 16 человек (22,2 \%). Исследование было проведено в 2018 г. в одной из школ Московской области для детей с особенностями развития.

\section{РЕЗУЛЬТАТЫ ИССЛЕДОВАНИЯ}

По итогам диагностики уровня эмоционального выгорания было выделено две группы испытуемых с уровнем выгорания выше и ниже 
среднего. Из них педагогов с уровнем выгорания выше среднего 30 человек $(41,7 \%)$ и ниже среднего - 42 человека (58,3 \%).

Результаты сравнения показателей эмоционального выгорания по группам представлены в табл. 1.

Таблица 1

\section{СРЕДНИЕ ЗНАЧЕНИЯ УРОВНЯ ЭМОЦИОНАЛЬНОГО ВЫГОРАНИЯ В ДВУХ ГРУППАХ ПЕДАГОГОВ}

\begin{tabular}{|l|c|c|}
\hline $\begin{array}{c}\text { Шкалы опросника } \\
\text { «эмциональное выгорание» }\end{array}$ & $\begin{array}{c}\text { Уровень } \\
\text { выше } \\
\text { среднего }\end{array}$ & $\begin{array}{c}\text { Уровень ниже } \\
\text { среднего }\end{array}$ \\
\hline Эмоциональное истощение & 2,50 & 1,14 \\
\hline Деперсонализация & 2,37 & 1,45 \\
\hline Профессиональная успешность & 1,14 & 2,23 \\
\hline Общий показатель & 2,37 & 1,25 \\
\hline
\end{tabular}

В группе с высоким уровнем эмоционального выгорания (первая группа) показатель эмоционального истощения равен 2,50 , в группе с низким уровнем эмоционального выгорания (вторая группа) - 1,14 (достоверность различий $U=9,98$, при $\mathrm{p} \leq 0,01$ по критерию Спирмена). Педагоги первой группы в большей степени чувствуют себя эмоционально истощенными. Для них характерно постоянное чувство усталости, которое не снимается сном, отдыхом. Утром до начала работы они нередко чувствуют усталость, а работа быстро их утомляет. Также они испытывают угнетенность и апатию, утрату интереса к тому, что интересовало их раньше.

Показатель деперсонализации в группе с высоким уровнем эмоционального выгорания равен 2,37, в группе с низким уровнем эмоционального выгорания 1,45 (достоверность различий $U=7,27$, при $\mathrm{p} \leq 0,01$ ). Педагоги первой группы испытывают потребность отстраняться от работы, от общения с коллегами и учащимися. Для них характерно ощущение враждебности со стороны администрации школы, учащихся, родителей, впечатление, что окружающие избыточно требуют их помощи, поддержки, участия. Им часто хочется уединиться, побыть в одиночестве.

Показатель профессиональной успешности в группе с высоким уровнем эмоционального выгорания равен 1,14, в группе с низким уровнем эмоционального выгорания 2,23 (достоверность различий $\mathrm{U}=7,71$, при $\mathrm{p} \leq 0,01$ ). 
Педагоги первой группы отмечают, что им бывает сложно понимать своих учеников, в целом общаться с ними. У них вызывает затруднение преодоление конфликтных ситуаций. Их профессиональные планы на будущее неясны, утратили привлекательность.

Общий показатель эмоционального выгорания в группе с высоким уровнем выгорания равен 2,37, в группе с низким уровнем 1,25. Выявленные различия статистически достоверны $(\mathrm{U}=17,2$, при $\mathrm{p} \leq 0,01$ по критерию Спирмена).

\section{ОСНОВНЫЕ ВИДЫ ЦЕННОСТНЫХ ОРИЕНТАЦИЙ В ДВУХ ГРУППАХ}

\begin{tabular}{|l|c|c|}
\hline \multicolumn{1}{|c|}{ Ценностные ориентации } & $\begin{array}{c}\text { Уровень выгорания } \\
\text { выше среднего }\end{array}$ & $\begin{array}{c}\text { Уровень } \\
\text { выгорания ниже } \\
\text { среднего }\end{array}$ \\
\hline Приятное времяпрепровождение & 3,03 & 3,02 \\
\hline $\begin{array}{l}\text { Высокое материальное } \\
\text { благосостояние }\end{array}$ & 2,43 & 1,98 \\
\hline $\begin{array}{l}\text { Поиск и наслаждение } \\
\text { интересным }\end{array}$ & 2,80 & 2,71 \\
\hline $\begin{array}{l}\text { Помощь и милосердие к другим } \\
\text { людям }\end{array}$ & 2,47 & 4,48 \\
\hline Любовь & 3,40 & 3,05 \\
\hline Познание нового в мире & 2,63 & 1,38 \\
\hline $\begin{array}{l}\text { Высокий социальный статус и } \\
\text { управление людьми }\end{array}$ & 1,20 & 3,55 \\
\hline $\begin{array}{l}\text { Признание и уважение людей, } \\
\text { влияние на окружающих }\end{array}$ & 3,07 & 2,14 \\
\hline $\begin{array}{l}\text { Социальная активность для } \\
\text { достижения позитивных } \\
\text { изменений в обществе }\end{array}$ & 1,00 & \\
\hline Общение & 2,47 & \\
\hline
\end{tabular}




\begin{tabular}{|l|r|r|}
\hline \hline Здоровье & 2,77 & 3,07 \\
\hline
\end{tabular}

В ходе исследования ценностных ориентаций было выявлено, что в обеих группах имеются общие ценности. Это, по всей видимости, отражает общую направленность тех людей, которые выбрали педагогическую деятельность. Так, для педагогов коррекционной школы обеих групп важна любовь (в первой группе среднее значение равно 4,05, во второй - 3,4).

Среди общих среднезначимых ценностей, схожих для двух групп, выявлены следующие: поиск и наслаждение интересным (средние значения 2,80 и 2,71), приятное времяпрепровождение (3,03 и 3,02 соответственно), здоровье $(2,77$ и 3,07$)$, общение $(2,47$ и 2,14$)$ и познание нового в мире $(2,63$ и 3,07). Среди малозначимых ценностей в обеих группах можно выделить высокий социальный статус и управление людьми (средние значения 1,20 и 1,38 соответственно) и социальную активность для достижения позитивных изменений в обществе $(1,00$ и 1,48$)$.

В сфере ценностных ориентаций были выявлены различия между группами. В частности, для педагогов, уровень эмоционального выгорания которых выше среднего, материальное благосостояние более значимо $(2,43)$, чем для педагогов с уровнем выгорания ниже среднего $(1,98)$. При этом для первой группы менее значимо уважение и признание людей и влияние на окружающих как ценность $(3,07)$, чем для второй группы $(3,55)$. Кроме того, меньшее значение имеет ценность помощи и милосердия к другим людям (в первой группе 2,47, во второй - 2,48).

Таким образом, для педагогов, уровень эмоционального выгорания которых выше среднего, в большей степени значимо (на уровне тенденций) материальное благосостояние, и менее важно признание и влияние на людей, чем для педагогов с уровнем ниже среднего, а также помощь и милосердие к другим людям.

Таблица 3

СРЕДНИЕ ЗНАЧЕНИЯ ПО СФЕРАМ

САМОАКТУАЛИЗАЦИИ В ГРУППАХ

\begin{tabular}{|c|c|c|}
\hline Сферы самоактуализации & $\begin{array}{c}\text { Уровень } \\
\text { выгорания } \\
\text { выше } \\
\text { среднего }\end{array}$ & $\begin{array}{c}\text { Уровень } \\
\text { выгорания } \\
\text { ниже среднего }\end{array}$ \\
\hline
\end{tabular}




\begin{tabular}{|l|c|c|}
\hline Стремление к самоактуализации & 51,93 & 54,00 \\
\hline Ориентация во времени & 12,75 & 13,89 \\
\hline Ценности & 8,5 & 9,2 \\
\hline Взгляд на природу человека & 6,85 & 7,9 \\
\hline Потребность в познании & 7,6 & 7,78 \\
\hline Креативность & 8,73 & 8,3 \\
\hline Автономность & 5,83 & 5,26 \\
\hline Спонтанность & 6,33 & 6,57 \\
\hline Самопонимание & 7,65 & 8,17 \\
\hline Аутосимпатия & 6,83 & 7,02 \\
\hline Контактность & 8,30 & 8,0 \\
\hline Гибкость в общении & 12,7 & 13,9 \\
\hline
\end{tabular}

У педагогов с уровнем эмоционального выгорания выше среднего показатель стремления к самоактуализации достоверно ниже $(51,93)$, чем у педагогов с уровнем выгорания ниже среднего $(54,00)$ (показатель достоверности различий $U=1,94$, при $p \leq 0,01)$. У педагогов первой группы более выражены затруднения в реализации своих способностей, ценностей и интересов, что делает их жизнь недостаточно яркой, обуславливает ощущение, что они живут «вполсилы».

Кроме того, педагоги этой группы менее креативны. Стоит отметить, что в данном случае различия имеют скорее характер тенденции. Эти педагоги отличаются большей ригидностью, склонностью следовать однажды выработанному способу мышления и деятельности. Данная характеристика снижает эффективность работы, качество взаимодействия с окружающими в постоянно меняющихся условиях. Их поведение становится менее адаптивным, а это, в свою очередь, обусловливает рост напряжения.

Они менее автономны, при этом для них характерна меньшая контактность. Педагоги данной группы зависимы от окружающих. Им крайне важно отношение к ним, оценка окружающих, статус и власть, что делает их зависимыми от мнения других. Но в то же время по сравнению с педагогами второй группы они менее расположены к взаимно полезным 
контактам с другими людьми, они также испытывают ощутимые трудности в установлении доброжелательных отношений с окружающими.

Таким образом, для педагогов с уровнем эмоционального выгорания выше среднего характерна затрудненная самоактуализация, тенденция к меньшей креативности, ригидность мышления, меньшая контактность и при этом большая зависимость от окружающих.

С целью выявления представлений о профессиональных целях и способах преодоления трудностей в работе у педагогов коррекционной школы применялся авторский вариант методики «Незаконченные предложения». Окончания фраз, дополненных респондентами, обрабатывались с помощью тематического контент-анализа. Для обработки данных применялся принцип частотности с подсчетом соответствующих категорий.

РАСПРЕДЕЛЕНИЕ КАТЕГОРИЙ В ЗАВЕРШЕНИИ ФРАЗЫ

Таблииа 4 «Я ВИЖУ СВОЮ ПРОФЕССИОНАЛЬНУЮ ЦЕЛЬ

В ТОМ, ЧТОБЫ...»

\begin{tabular}{|l|c|c|c|c|}
\hline $\begin{array}{c}\text { Категории контент- } \\
\text { анализа }\end{array}$ & \multicolumn{2}{|c|}{$\begin{array}{c}\text { Уровень } \\
\text { выгорания выше } \\
\text { среднего }\end{array}$} & \multicolumn{2}{|c|}{$\begin{array}{c}\text { Уровень выгорания } \\
\text { ниже среднего }\end{array}$} \\
\hline & $\begin{array}{c}\text { Количество } \\
\text { респондентов }\end{array}$ & $\begin{array}{c}\text { Количество } \\
\text { респондентов }\end{array}$ & $\%$ \\
\hline $\begin{array}{l}\text { Направленность на } \\
\text { других }\end{array}$ & 19 & 63 & 29 & 69 \\
\hline & 9 & 30 & 9 & 21 \\
\hline Направленность на себя & 2 & 6,7 & 4 & 9,5 \\
\hline Неопределенность & & & & \\
\hline
\end{tabular}

По данным авторского варианта методики «Незаконченные предложения», можно сделать выводы о том, что педагоги с высоким уровнем эмоционального выгорания, как и педагоги с низким уровнем эмоционального выгорания преимущественно связывают цель своей профессиональной деятельности с другими людьми. Большая часть реплик - «приносить пользу людям», «помогать детям» и т. д. (63\% и 69 \% соответственно). Для первой группы эта тенденция выражена в меньшей степени. 
Направленность на себя преобладает в группе с уровнем эмоционального выгорания выше среднего (30 \% и $21 \%$ соответственно). Педагоги данной группы в большей степени видят цель своей профессиональной деятельности в повышении квалификации, учебе, самосовершенствовании. В то же время эти цели не носят смыслообразующего характера: выполнение деятельности осуществляется ради нее самой, а не ради результата. В связи с этим педагоги могут сталкиваться с утратой смысла своей деятельности, в частности в ситуации трудностей и повышенных нагрузок.

\section{РАСПРЕДЕЛЕНИЕ КАТЕГОРИЙ В ЗАВЕРШЕНИИ ФРАЗЫ «ПСИХОЛОГИЧЕСКИЕ СЛОЖНОСТИ В РАБОТЕ МНЕ ПОМОГАЕТ ПРЕОДОЛЕВАТЬ...»}

\begin{tabular}{|l|c|c|c|c|}
\hline $\begin{array}{c}\text { Категории контент- } \\
\text { анализа }\end{array}$ & $\begin{array}{c}\text { Уровень } \\
\text { выгорания выше } \\
\text { среднего }\end{array}$ & \multicolumn{2}{|c|}{$\begin{array}{c}\text { Уровень выгорания } \\
\text { ниже среднего }\end{array}$} \\
\hline & $\begin{array}{c}\text { Количество } \\
\text { респондентов }\end{array}$ & $\%$ & $\begin{array}{c}\text { Количество } \\
\text { респондентов }\end{array}$ & $\%$ \\
\hline Другие люди & 8 & 27 & 14 & 33 \\
\hline Я сам & 19 & 63 & 8 & 19 \\
\hline & 3 & 10 & 19 & 45 \\
\hline Другая деятельность & & & & \\
\hline
\end{tabular}

Для преодоления психологических сложностей в работе педагоги с уровнем выгорания выше среднего опираются преимущественно на собственные ресурсы, на «личные внутренние качества», «критический подход к себе» (63\%), во второй группе (19\%). При этом, в отличие от педагогов второй группы, респонденты первой группы в меньшей степени обращаются за помощью к другим людям (27\% и 33 \%): семье, коллегам, друзьям. Кроме того, педагоги первой группы слабо используют возможности переключения на другой вид деятельности (10\% и 45\% соответственно): отдых, чтение, музыка и т. д. Т. е. они уделяют большую часть времени педагогической деятельности. Для них характерен узкий круг способов преодоления психологических трудностей, преимущественно связанный с их личностными ресурсами. Они изолируются от окружающих, а также 
практически не используют ресурс смены видов деятельности для релаксации.

РАСПРЕДЕЛЕНИЕ КАТЕГОРИЙ

Таблий 6

В ЗАВЕРШЕНИИ ФРАЗЫ «Я СТРЕМЛЮСЬ...»

\begin{tabular}{|l|c|c|c|c|}
\hline \multicolumn{1}{|c|}{\begin{tabular}{c}
\multicolumn{1}{c|}{$\begin{array}{c}\text { Уровень } \\
\text { анализа }\end{array}$} \\
\hline
\end{tabular}} & $\begin{array}{c}\text { Когорания выше } \\
\text { среднего } \\
\text { Келичество }\end{array}$ & $\begin{array}{c}\text { Уровень выгорания } \\
\text { ниже среднего }\end{array}$ \\
\hline $\begin{array}{l}\text { ртремления, связанные с } \\
\text { другими }\end{array}$ & 3 & $\begin{array}{c}\text { Количество } \\
\text { респондентов }\end{array}$ & $\%$ \\
\hline $\begin{array}{l}\text { Стремления, связанные с } \\
\text { собой }\end{array}$ & 10 & 33 & 22 & $\mathbf{5 2}$ \\
\hline Неопределенность целей & 17 & $\mathbf{5 7}$ & 17 & 40 \\
\hline
\end{tabular}

При сравнении двух групп у педагогов с уровнем эмоционального выгорания выше среднего наблюдается неопределенность целей (57\% и 40 \% соответственно). В результате этого педагоги первой группы могут сталкиваться с недостаточным осознанием ориентиров в жизни и профессии. Также у них наблюдается более низкая выраженность стремлений, связанных с ними самими и собственным благополучием (33 \% и 52 \% соответственно). Для педагогов с уровнем эмоционального выгорания выше среднего характерна недостаточная ясность жизненных и профессиональных ориентиров, что позволяет предположить слабую структурированность, осознанность жизненной перспективы. Это выступает существенным дезорганизующим фактором, который способен усугублять профессиональное выгорание педагогов.

Таблииа 7

РАСПРЕДЕЛЕНИЕ КАТЕГОРИЙ В ЗАВЕРШЕНИИ ФРАЗЫ «МОЙ УСПЕХ СВЯЗАН С...»

\begin{tabular}{|c|c|c|}
\hline $\begin{array}{c}\text { Количество } \\
\text { респондентов }\end{array}$ & \begin{tabular}{|} 
Уровень \\
выгорания выше
\end{tabular} & $\begin{array}{c}\text { Уровень выгорания } \\
\text { ниже среднего }\end{array}$ \\
\hline
\end{tabular}




\begin{tabular}{|l|c|c|c|c|}
\hline & \multicolumn{2}{|c|}{ среднего } & \multicolumn{2}{c|}{} \\
\hline & $\begin{array}{c}\text { Количество } \\
\text { респондентов }\end{array}$ & $\%$ & $\begin{array}{c}\text { Количество } \\
\text { респондентов }\end{array}$ & $\%$ \\
\hline Собственные усилия & 24 & 80 & 32 & 76 \\
\hline Помощь окружающих & 4 & 13 & 8 & 19 \\
\hline Внешние условия & 2 & 6,7 & 2 & 4,8 \\
\hline
\end{tabular}

Большинство педагогов с уровнем выгорания выше среднего (80 \%) связывают свой профессиональный успех с собственными усилиями. Однако во второй группе большее количество педагогов учитывают вклад окружающих в их успехи (19\%), а педагоги первой группы склонны замечать этот аспект в меньшей степени (13\%), как и влияние внешних условий $(6,7 \%$ и $4,8 \%$ соответственно).

Большинство педагогов первой группы (80\%) склонны преимущественно приписывать себе успехи в своей деятельности, недооценивая вклад других людей или объективных обстоятельств. Это существенно ограничивает возможность принятия поддержки от окружающих, разделения ответственности со всеми участниками педагогического процесса.

Таблица 8

РАСПРЕДЕЛЕНИЕ КАТЕГОРИЙ В ЗАВЕРШЕНИИ ФРАЗЫ «МОЙ ПРОФЕССИОНАЛЬНЫЙ ИНТЕРЕС НАПРАВЛЕН НА...»

\begin{tabular}{|c|c|c|c|c|}
\hline $\begin{array}{c}\text { Категории контент } \\
\text { анализа }\end{array}$ & $\begin{array}{c}\text { Уровень } \\
\text { выгорания выше } \\
\text { среднего }\end{array}$ & \multicolumn{2}{|c|}{$\begin{array}{c}\text { Уровень выгорания } \\
\text { ниже среднего }\end{array}$} \\
\hline & $\begin{array}{c}\text { Количество } \\
\text { респондентов }\end{array}$ & $\begin{array}{c}\text { Количество } \\
\text { респондентов }\end{array}$ & $\%$ \\
\hline На себя & 19 & 63 & 15 & 36 \\
\hline
\end{tabular}




\begin{tabular}{|l|c|c|c|c|}
\hline $\begin{array}{l}\text { Вовне (работа, другие } \\
\text { люди) }\end{array}$ & 5 & 17 & 18 & 43 \\
\hline Неопределенно & 6 & 20 & 9 & 21 \\
\hline
\end{tabular}

Профессиональный интерес педагогов, уровень эмоционального выгорания которых выше среднего, направлен, в отличие от второй группы, в большей степени на самих себя (63 \% и 36 \% соответственно). При этом у педагогов первой группы в сравнении со второй выявляется недостаток профессионального интереса, который связан с взаимодействием с окружающими. Педагоги с уровнем выгорания выше среднего связывают профессиональные интересы в большей степени с самими собой, своим развитием и самосовершенствованием, практически не уделяя внимания построению партнерских взаимоотношений с другими людьми. Можно предположить, что, воспринимая себя как основных субъектов педагогического взаимодействия, они в большей степени сосредоточиваются на себе, своих качествах и умениях, при этом игнорируя тот факт, что существенную роль в любой коллективной деятельности, играют все его участники (ученики, педагоги, родители). Педагоги данной группы стремятся управлять процессом взаимодействия самостоятельно, принимая на себя всю ответственность за его содержание. Это существенно увеличивает психологическую нагрузку на них самих. А при столкновении с трудностями, они предпочитают преодолевать их в одиночку, без поддержки окружающих, что только усиливает нагрузку. Такое восприятие профессиональной деятельности, безусловно, может быть рассмотрено как сопряженное с высоким риском эмоционального выгорания педагога.

Полученные результаты позволяют сделать вывод о том, что для педагогов с уровнем эмоционального выгорания выше среднего характерно более выраженное эмоциональное истощение, усталость от общения с учащимися, коллегами, администрацией и от педагогической деятельности. Это обусловливает также их стремление отстраниться от работы и общения с окружающими. Для педагогов данной группы характерна более низкая оценка своей профессиональной успешности, ощущение, что их деятельность не приносит пользы учащимся, она малоэффективна. Педагоги с уровнем эмоционального выгорания ниже среднего отличаются тем, что испытывают интерес к выполняемой деятельности, общению с учащимися и педагогами. В случае усталости они довольно быстро восстанавливаются. При этом их самооценка профессиональной успешности находится на более высоком уровне, они удовлетворены своими результатами в настоящем и строят планы на будущее. 


\section{ЗАКЛЮЧЕНИЕ}

Обнаруженные в исследовании личностные факторы эмоционального выгорания педагогов коррекционной школы можно интерпретировать в контексте психологического здоровья педагогических работников. Полученные результаты сопоставимы с факторной структурой психологического здоровья педагога, которая включает духовный фактор или «направленность на других, служение другому» и самореализацию, индивидуально-личностный фактор или «направленность на себя», а также социальный фактор (Федосенко и др., 2012). Таким образом, можно предположить, что для педагогов коррекционной школы с высоким уровнем эмоционального выгорания характерны следующие нарушения психологического здоровья: дефицит духовного начала в педагогической деятельности, слабо выраженное стремление оказать помощь и проявить милосердие по отношению к другим людям при высокой ценности материального благосостояния; своеобразие индивидуальноличностных особенностей (слабая направленность на самоактуализацию); недостаточная ориентация на продуктивные отношения с близким окружением (слабость социальных контактов).

Сегодня проблема эмоционального выгорания остро стоит для педагогов коррекционных школ. Это обусловлено такими причинами как особая сложность контингента обучающихся в таких школах, а также низкий уровень специальной дефектологической подготовки педагогов. Однако ключевая роль в эмоциональном выгорании этой категории педагогов принадлежит их личностным характеристикам. Несмотря на значительное число работ по проблеме эмоционального выгорания педагогов результаты нашего исследования показывают, что в практике образовательной деятельности остается еще много нерешенных проблем, связанных с профессионализацией и психологическим здоровьем педагогов коррекционных школ.

\section{СПИСОК ЛИТЕРАТУРЫ}

Айсина, Р. М. (2007) Влияние личностных факторов на эмоциональное выгорание менеджеров в условиях коммерческой организации : автореф. дис. ... канд. псих. н. / Рос. гос. социал. ун-т. М. 27 с.

Бойко, В. В. (1999) Синдром «эмоционального выгорания» в профессиональном общении. СПб. : Питер. 105 с.

Василевская, Е. А. (2011) Профессиональное здоровье педагога как фактор совершенствования здоровьесберегающей образовательной среды // Вектор науки ТГУ. № 1 (15). С. 375-378.

Водопьянова, Н. Е. (2000) Синдром психического выгорания в коммуникативных профессиях // Психология здоровья / под ред. Г. С. Никифорова. СПб. : Изд-во СПбГУ. 504 с. С. 443-463. 
Водопьянова, Н. Е. (2009) Психодиагностика стресса. СПб. : Питер. 336 c. $544 \mathrm{c}$.

Гришина, Н. В. (2008) Психология конфликта. 2-е изд. СПб. : Питер.

Орел, В. Е. (2001) Феномен «выгорания» в зарубежной психологии: эмпирические исследования [Электронный ресурс] // Журнал практической психологии и психоанализа. № 3. URL: http://psyjournal.ru/articles/fenomenvygoraniya-v-zarubezhnoy-psihologii-empiricheskie-issledovaniya [архивировано в WaybackMachine] (дата обращения: 15.06.2018).

Психологическое здоровье личности и духовно-нравственные проблемы современного российского общества (2014) / отв. ред. А. Л. Журавлев, М. И. Воловикова, Т. В. Галкина. М. : Институт психологии РАН. 318 с.

Редина, Т. В. (2010) Эмоциональное выгорание педагогов специальных коррекционных образовательных учреждений // Знание. Понимание. Умение. № 1. C. 222-227.

Умняшкина, С. В. (2001) Синдром эмоционального выгорания как проблема самоактуализации личности (в сфере помогающих профессий): автореф. дис. ... канд. псих. наук. / Том. гос. ун-т. Томск. 22 с.

Федосенко, Е. В. и др. (2012) Психология самореализации профессионала / под ред. Е. В. Федосенко. СПб. : Речь. 156 с.

Феофанов, В. Н. (2008) Психическое выгорание специальных педагогов и его влияние на психологическое благополучие учащихся с отклонениями в развитии : дис. ... канд. псих. наук. Нижний Новгород. 249 с.

Феофанов, В. Н. (2009) Психическое выгорание специальных педагогов и его влияние на психологическое благополучие учащихся с отклонениями в развитии : автореф. дис. ... канд. псих. наук. Нижний Новгород. 27 с.

Maslach, C., Jackson, S. E. (1986) Maslach burnout inventory : manual ; with a special supplement "Burnout in education". 2nd edn. Palo Alto, CA : Consulting Psychologists Press. v, 34 p.

Дата поступления: 15.09.2018 2.

Емельянова Татьяна Петровна - доктор психологических наук, ведущий научный сотрудник лаборатории социальной и экономической психологии Института психологии РАН; профессор кафедры социальной и этнической психологии Московского гуманитарного университета. Адрес: 129366 , Россия, г. Москва, ул. Ярославская, д. 13, корп. 1. Тел.: +7 (495) 683-38-09. Эл. адрес:

Emelyanova Tatiana Petrovna, Doctor of Psychology, Leading Researcher, Laboratory of Social and Economic Psychology, Institute of Psychology, Russian Academy of Sciences; Professor, Department of Social and Ethnic Psychology, Moscow University for the Humanities. Postal address: 13, Yaroslavskaya St., 129366 Moscow, Russian Federation. Tel.: +7 (495) 683-38-09. E-mail: t_emelyanova@inbox.ru 
SPIN-код РИНЦ: 4338-1645; SCOPUS ID: 6508104219.

Шуралева Екатерина Игоревна - магистрант кафедры социальной и этнической психологии Московского гуманитарного университета. Адрес: 111395, Россия, г. Москва, ул. Юности, 5. Тел.: +7 (499) 374-51-51. Эл. адрес: shuralevaei@mail.ru

Shuraleva Ekaterina Igorevna, Master Student, Department of Social and Ethnic Psychology, Moscow University for the Humanities. Postal address: 5, Yunosti St., 111395 Moscow, Russian Federation. Tel.: +7 (499) 374-51-51. Email: shuralevaei@mail.ru

Для ичитирования:

Емельянова Т. П., Шуралева Е. И. Личностные факторы эмоционального выгорания педагогов коррекционной школы [Электронный ресурс] // Горизонты гуманитарного знания. 2018. № 5. С. 67-84. URL: http://journals. mosgu.ru/ggz/article/view/867 (дата обращения: дд.мм.гггг). DOI: 10.17805/ ggz.2018.5.6 